\title{
Salk Institute investigated after claims of inhumane research
}

[SAN DIEGO] Federal authorities are investigating animal research at the Salk Institute, after past inhumane treatment and faulty experiments were exposed in a civil court case brought by a former employee.

The animal research programme at the institute in La Jolla, California, was so rife with problems at one stage that the success of scientific projects was threatened, the San Diego court heard.

Teresa J. Sylvina, a veterinarian hired in 1990 to correct animal research deficiencies at the Salk, is suing the institute for wrongful termination, retaliation, defamation and sexual harassment.

Most of the difficulties - ranging from deadly disease in animals to failed surgical techniques — occurred in the early 1990s, when the institute was trying to bring its programme into compliance with a 1985 animal care law. But internal strife over methods has lingered between scientists and administrative staff at the Salk, the court was told.

The federal investigation, launched last week, is being conducted by the US Department of Agriculture, which licenses animal research facilities, together with the Office for Protection from Research Risks at the National Institutes of Health (NIH).

Salk Institute officials say they have corrected the problems and now operate a firstrate animal research programme. They say they welcome the probe, which they anticipate will exonerate the facility.

Sylvina was fired in 1996, and now directs animal research at the Tufts University School of Veterinary Medicine in Boston, Massachusetts. But she told the court she was blackballed for more than a year by Salk Institute officials, in particular Nobel laureate Francis Crick, who once ran the institute on an interim basis.

The court heard about intense acrimony between Sylvina and Crick, who engaged in a "screaming match" in 1995. Crick couldn't be reached for comment last week.

Salk Institute officials contend that Sylvina was a bad manager. "There is no basis for the allegations presented by Sylvina in her lawsuit," said Fred H. Gage, chairman of the institute's faculty.

But some court records and sworn testimony support Sylvina's claims, and indicate that the institute's faculty was divided on her performance. Robert Hyman, a senior scientist at the institute who chaired the Animal Care and Use Committee, testified that, before Sylvina came aboard, "there was so much disease in the [animal] facility that people couldn't do experiments".

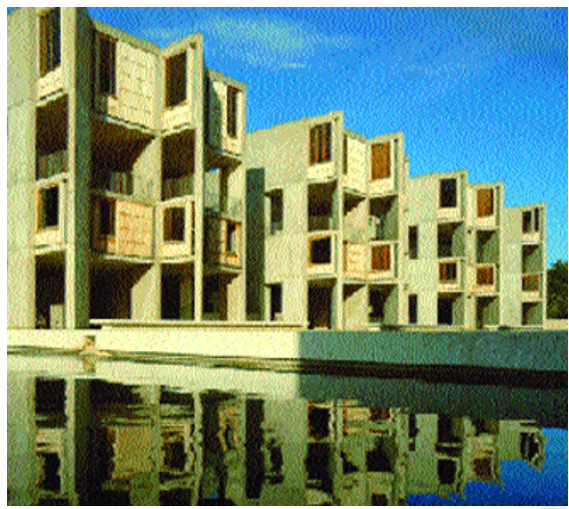

Troubled waters: Salk Institute animals were too sick for use in experiments, one scientist testified.

A major NIH cancer grant to the institute was threatened by the animal research deficiencies, Sylvina told the court. The institute's animal committee was "a dead-letter" panel, she said, which did not properly review or monitor experiments. Sylvina uncovered instances of inhumane and faulty experiments. But court records show the committee was reluctant to discipline scien-

tists. A neuroscientist who caused a number of problems, including accidentally burning one cat severely and asphyxiating another, was permitted to avoid a serious sanction, which would have been reported to NIH officials. The neuroscientist voluntarily halted his experiments and later left the institute.

When Sylvina was fired, Hyman testified that he resigned from the animal committee, believing she had been sacked for doing a good job. "She started with a failing facility there, she led a revolution there, which is never very comfortable for those in the status quo," Hyman testified. He declined to be interviewed for this article.

Federal authorities are also to examine claims of questionable NIH billing practices. Sylvina testified that she discovered a staff member of the animal department doublebilling for experiments, but that administrators at the institute failed to aggressively pursue her concerns. A Salk administrator testified that the institute had given a monetary advance to the staff member, whose wages had been cut when Sylvina halted the questionable billing practice.

Rex Dalton

\section{India set to allow patents for products}

[NEW DELHI] India is to join the Paris Convention of the World Intellectual Property Organization (WIPO), in a move which is expected to bring a major liberalization of its patent laws.

The decision, which will simplify both international patenting for Indian scientists and the exploitation of international patents in India, was welcomed by scientists but criticized by some environmentalists.

"This is going to give our scientists tremendous impetus for research," says Ragunath Mashelkar, head of the Council of Scientific and Industrial Research, India's largest government scientific agency.

"It will lead to a lot of savings in the patenting process," says Suresh Chandran, an expert on patents at the National Institute of Immunology in New Delhi.

Under India's 1970 Patents Act, inventors of new chemicals or drugs can only patent manufacturing processes, not products. As a member of the World Trade Organization, India is already obliged to provide product patents by 2005 . Changes to the 1970 act were resisted by the Bharatiya Janata Party (BJP) when it was in opposition, and last week's decision by the BJP government to join the Paris convention is seen as a signal that a change in the law is imminent.
Mashelkar says membership will allow Indian inventors access to WIPONET, a \$20 million computerized database on patents. India also becomes eligible to join the Budapest Treaty, allowing its scientists to maintain patentable microorganisms in their own repository instead of having to deposit them with one of the 26 repositories abroad recognized by the treaty.

Foreign scientists may now find the Indian patent regime less rigid, according to Chandran, because applications from member countries have to be given priority. Under the convention, a patent may not be refused because domestic law does not permit it - an indication that India plans to amend its law against product patents.

Vandana Shiva, an environmental activist, says that India will now come under pressure from multinationals to introduce product patents for drugs. She adds that drug prices rose by 20 per cent in Pakistan after it signed the convention in 1994.

Joining the convention before implementing biodiversity laws will, Shiva warns, "facilitate biopiracy globally and create a perverted situation, in which Indian patent offices will recognize patents based on biopiracy of Indian indigenous knowledge systems".

K.S. Jayaraman 